\title{
Cyberprzestrzeń i mass media sprzymierzeńcem duchowości?
}

Zasygnalizowany w tytule temat jest bardzo obszerny, dotyczy przecież rzeczywistości złożonych, bogatych w treści. Zarówno duchowość chrześcijańska jak i cyberprzestrzeń oraz mass media odgrywają bardzo znaczącą rolę w życiu człowieka, warunkując na przykład jego postępowanie i losy. Stąd wskazanej problematyce warto poświęcić uwagę, nawet jeśli mamy do czynienia z przyczynkiem do jej opracowania, do bardziej owocnego spotkania między duchowością oraz cyberprzestrzenią i mediami.

\section{Duchowość i cyberprzestrzeń. Obcość,}

wrogość czy współdziałanie?

Cyberprzestrzeń i mass media kojarzą się z czasami współczesnymi, z dynamicznym rozwojem technicznym. Postrzegana jest jako nowość ${ }^{1}$. Natomiast duchowość chrześcijańska - nie bez racji - jest oceniana jako silnie związana z historią, na przykład ze starożytnością. Czy nie oznacza to, że nie dokonuje się spotkanie między duchowością a cyberprzestrzenią i mediami, lub że ewentualnie jest to spotkanie między coraz mniej aktualną, coraz mniej znaczącą duchowością i coraz ważniejszymi, rozwijającymi się mediami i cyberprzestrzenią? Może nawet ktoś dopatrywałby się konfliktu między duchowością i tymi ostatnimi, na przykład wrogości ze strony duchowości czy zwalczania, marginalizowania, uśmiercania jej przez cyberprzestrzeń, przez media. Wskazane poniżej dane prowadzą raczej do wniosku, iż przede wszystkim mamy tu do czynienia z dwoma znaczącymi rzeczywistościami, które mocno i często splatają się ze sobą i przenikają, wpływają na siebie. Nie widać też powodów, by ta sytuacja miała ulec zmianie.

\footnotetext{
${ }^{1}$ Por. I. Stolarczyk, Dylematy globalizacji. Kryteria wartościowania zmian społecznych w kontekście nauczania społecznego Kościoła, Tarnów 2003, s. 88n.
} 
Nietrudno wykazać, że oddziaływanie mediów jest wieloznaczne, nieraz nawet groźne. Dokładniej mówiąc, one są instrumentem. Jak niejedno narzędzie mogą się one wymknąć spod ludzkiej kontroli, jednak właściwe osobie ludzkiej zdolność przewidywania konsekwencji i odpowiedzialność odgrywają tutaj pierwszorzędną rolę. Wskazuje na to na przykład Papieska Rada ds. Środków Społecznego Przekazu: „Sposób, w jaki ludzie korzystają ze środków społecznego przekazu, może być źródłem wielkiego dobra i wielkiego zła"2. Zwraca na to uwagę bł. Jan Paweł II: „Wielka i poważna odpowiedzialność spoczywa na pracownikach środków przekazu: mają oni troszczyć się o to, aby treści przekazywane w sposób tak skuteczny służyły kulturze życia. Winni zatem ukazywać wzniosłe i szlachetne przykłady życia i poświęcać uwagę pozytywnym, a czasem wręcz heroicznym świadectwom ludzkiej miłości"3. Dają o sobie znać również obawy, że mass media zajmą zbyt ważne miejsce, co wpłynie niekorzystnie na inne obszary życia. „Na łamach dzisiejszego [25 X 2010] wydania «Corriere della Sera» Vittorio Messori uspokaja wszystkich, którzy odebrali orędzie Benedykta XVI na tegoroczny Światowy Dzień Środków Społecznego Przekazu pod tytułem Kapłan i duszpasterstwo w świecie cyfrowym: nowe media w stużbie Słowa jako zapowiedź przenosin Kościoła do Internetu. «Tak się nie stanie» - stwierdza włoski pisarz katolicki. [...] Vittorio Messori zauważa, że dzięki Internetowi nastąpił rozkwit apologetyki, «rozumianej jako obrona porozumienia wiary i rozumu, historii i Biblii, Kościoła i Ewangelii»"4.

Nie bez racji cyberprzestrzeń i media są postrzegane jako zagrożenie, jako faktyczne lub potencjalne narzędzie wyrządzania krzywdy. Pojawiają się tu różne poważne niebezpieczeństwa: na przykład szerzenie nienawiści, nietolerancji, ośmieszanie, wprowadzanie w błąd. Przybierają one postać m.in. chrystianofobii czy katalikofobii ${ }^{5}$. Niestety, nie wszyscy stosują się do zasady, iż dobro osoby to zasadnicze kryterium przekazu informacji ${ }^{6}$. Samo dobro bywa też różnie rozumiane. Warto w tym kontekście zacytować papieża Benedykta XVI: „W krajach i częściach krajów, które wcześniej liczyły 90 i więcej procent katolików, udział ten zmniejszył się do 60 procent. [...] postępuje sekularyzacja, która dzięki masowym

${ }^{2}$ Papieska Rada ds. Środków Społecznego Przekazu, Etyka w środkach społecznego przekazu (4 VI 2000), 1, www.opoka.org.pl (21.05.2012).

${ }^{3}$ Jan Paweł II, Enc. Evangelium vitae, 98.

${ }^{4}$ [b.a.] Nie będzie cyber-księży, cyfrowego Kościoła ani web-gospel. Vittorio Messori komentuje echa orędzia Benedykta XVI na 44. Dzień Środków Spotecznego Przekazu, http://ekai.pl (24.05.2012).

${ }^{5}$ Por. Jan Paweł II, W trosce o lepsza przyszłość rodziny ludzkiej. Spotkanie z korpusem dyplomatycznym (12 I 2004), 3, „L'Osservatore Romano” 3 : 2004, s. 139; K. Misiewicz, Chrystianofobia w chrześcijańskiej Europie?!, „Katecheta” 3 :2012, s. 15n; [b.a.], Abp Mamberti apeluje o wolność religijna w Europie, www.opoka.org.pl (7.12.2011); [b.a.], AI: wzrost chrystianofobii w świecie jest faktem, www.opoka.org.pl (1.05.2011).

${ }^{6}$ K. Ołdakowski, Media pod lupa, Kraków 2010, s. 90. 
mediom ma mocny wpływ i przemienia świadomość ludzi"7. Oto jeszcze jeden dający do myślenia przyczynek do omawianego tematu. „Scaraffia odpowiada: «Owszem, było nieporozumienie, było nim celowe niezrozumienie i sprowadzenie wszystkich kwestii o znacznie szerszym zasięgu do określonej sytuacji historycznej»”. I natychmiast potem: „Nieprzychylny klimat w mediach panuje przez kolejne miesiące po śmierci Montiniego, a także po 16 października 1978 roku. Wydaje się to niemożliwe, lecz - jak powiedział [...] Andrea Riccardi - «Jan Paweł II był także papieżem niepopularnym». [...] jest to bowiem mechanizm, który powtarza się niemal za każdym razem. W swoistej grze, polegającej na przeciwstawianiu sobie papieży, w zestawieniu z nowo wybranym papieżem poprzednik zyskuje na wartości: «Pawłowi VI, papieżowi trudności i mediacji, przeciwstawia się nieugiętego papieża Polaka, trzymającego się kurczowo wzorców klerykalnych i przedpoborowych». Wystarczy przytoczyć tytuł artykułu Eugenia Scalfariego: Nie Jan Pawet II, ale Pius XII. Był to rok 1979"8.

Jak jeszcze zobaczymy, zarazem cyberprzestrzeń i media jawią się jako pozytywny protagonista życia i sojusznik duchowości. Przybiera to postać na przykład udostępniania informacji, umożliwiania spotykania się, prezentowania atutów właściwych chrześcijaństwu i uzasadniania ich przydatności dla współczesnego człowieka. Nasuwa się tu podstawowe pytanie: Czy w przypadku mediów i duchowością mamy do czynienia z przewagą elementów negatywnych czy pozytywnych? Czy media odgrywają bardziej rolę pozytywną, czy negatywną? Już przytoczone powyżej dane stanowią przesłankę, by nie szukać tutaj pochopnie łatwych odpowiedzi.

\section{Przydatność duchowości dla cyberprzestrzeni i mediów}

Zagadnienie przydatności duchowości chrześcijańskiej dla cyberprzestrzeni i mediów stanowi część szerszej problematyki, a mianowicie wkładu chrześcijaństwa w rozwój poszczególnych ludzi i świata. Zaznajomienie się z danymi, jakich obficie dostarcza historia, prowadzi do wniosku, że chrześcijaństwo przez nacisk na miłość, solidarność, odpowiedzialność za siebie i innych, wskazywanie na potrzebę bycia aktywnym, kompetentnym przyczyniło się - nieraz w trudnych okolicznościach - do trwałego wysunięcia się narodów europejskich i tworzonej przez nie szeroko rozumianej cywilizacji naukowej, ekonomicznej i politycznej na czoło w skali światowej.

W jakim sensie duchowość chrześcijańska jest przydatna cyberprzestrzeni i mediom, czyli tworzącym je i odbierającym je ludziom, wskazuje na przykład Jan

${ }^{7}$ Świattość świata. Papież, Kościót i znaki czasu. P. Seewald rozmawia z Benedyktem XVI, Kraków 2011, s. 124-125; por. też s. 63-64, 76, 126.

${ }^{8}$ G. Galeotti, Media a Kościót katolicki: historia niezrozumienia. Kongres zorganizowany w Watykanie przez „L'Osservatore Romano”, www.opoka.org.pl (05.11.2012). 
Paweł II. Wczytując się w poniżej przytoczone słowa, teolog z łatwością dojdzie do wniosku, iż chodzi o pomoc wartościową i niezbędną.

Również świat mediów potrzebuje Chrystusowego odkupienia. W analizowaniu procesów zachodzących w dziedzinie środków przekazu i ich wartości w perspektywie wiary niewątpliwie pomocne może być zgłębianie Pisma Świętego. Jawi się ono bowiem jako „wielki kodeks” przekazu przesłania, które nie jest tylko chwilowe i okazjonalne, ale fundamentalne, ze względu na jego wymiar zbawczy9.

Cyberprzestrzeń i media nie są poza polem Bożego dobroczynnego zainteresowania i skutecznego zbawczego działania. Należą do rzeczywistości stworzonych i już w tym podstawowym sensie Bóg na zawsze związał je ze sobą. A przecież Bóg nie działa bezcelowo, ale zawsze jest powodowany miłością, troską o przyszłość (por. Ef 1,3). Wskazana pomoc może realizować się jako wspieranie i rozwijanie duchowości ludzi mediów.

ważne jest zapewnienie formacji i opieki duszpasterskiej osobom pracującym zawodowo w dziedzinie przekazu społecznego. Często spotykają się one w codziennej pracy z silnymi naciskami i z dylematami etycznymi; wielu z nich ,szczerze pragnie wiedzieć, co jest etycznie i moralnie godziwe, i zgodnie z tym postępować", i oczekuje od Kościoła wskazań i pomocy ${ }^{10}$.

Zacytowane słowa najpierw odnoszą się do ewangelizacji. Jednak wskazują też na możliwości chrześcijańskiego wkładu w czynienie z cyberprzestrzeni i mediów środowiska, narzędzia przyjaznego życiu. Istotę takiego zaangażowania sprowadza się do naśladowania Chrystusa przez chrześcijan, by w ten sposób z wzoru i pomocy udzielanej przez Niego mogli skorzystać także inni.

Forma przekazu, potrzebna do głoszenia Ewangelii, musi być nacechowana szacunkiem i wrażliwością, pobudzać serce i poruszać sumienie; musi wzorować się na Jezusie zmartwychwstałym, który jako towarzysz drogi dołączył do uczniów z Emaus (por. Łk 24, 13-35) i stopniowo prowadził ich do zrozumienia tajemnicy poprzez rozmowę, łagodne wydobywanie tego, co kryło się w ich sercu. [...] Prawda, którą jest Chrystus, w ostatecznym rozrachunku stanowi pełną i autentyczną odpowiedź na to ludzkie pragnienie relacji, wspólnoty i sensu, które przejawia się także w ogromnej popularności rozmaitych social networks. Wierzący, dając świadectwo swoim najgłębszym przekonaniom, pomagają w zabieganiu o to, by sieć nie stała się narzędziem traktującym ludzi bezosobowo, usiłującym manipulować ich uczuciami lub dającym osobom wpływowym monopol na kształtowanie opinii innych. Przeciwnie, wierzący zachęcają wszystkich, by wciąż zadawali sobie odwieczne pytania człowieka, które świadczą o jego pragnieniu transcendencji i tęsknocie za autentycznymi formami życia, godnymi tego, by żyć. Właśnie to dążenie duchowe, typowo ludzkie, każe nam szukać prawdy i wspólnoty oraz porozumiewać się w sposób prawy i uczciwy ${ }^{11}$.

W cyberprzestrzeni i w mediach Bóg jest obecny, daje się znaleźć, pomaga. Człowiekowi trzeba zaś pomóc dostrzec tę szansę i skorzystać z niej.

${ }^{9}$ Jan Paweł II, Szybki rozwój. List apostolski do odpowiedzialnych za środki społecznego przekazu (24 I 2005), 4, www.kuria.lomza.pl (27.02.2010).

${ }^{10}$ Tamże, 9.

${ }^{11}$ Benedykt XVI, Nowe technologie komunikacyjne i głoszenie Ewangelii. Orędzie na 45. Światowy Dzień Środków Społecznego Przekazu 2011 roku (24 I 2011), www.opoka.org.pl (31.08.2011). 
Do czego prowadzi odrzucenie, zwalczanie, eliminowanie chrześcijaństwa i tym samym jego duchowości, jednoznacznie pokazuje pozostawiona przez totalitaryzmy hitlerowski i komunistyczny spuścizna, gdy chodzi na przykład o stan gospodarki, rozwój ekonomiczny. Oba te totalitaryzmy doceniały mass media jako narzędzie dla realizacji swych celów i trudno nie przyznać, iż potrafiły one skorzystać $\mathrm{z}$ atutów dawanych przez media. To samo zapewne zrobiłyby z cyberprzestrzenią, jeśli tylko miałyby do niej dostęp.

\section{Cyberprzestrzeń i media: pomoc cenna, niezbędna dzisiaj}

Zastanawiając się nad cyberprzestrzenią i mediami jako pomocą dla duchowości, czyli dla człowieka, jego otoczenia, świata, nie można nie zwrócić uwagi, iż skorzystanie z tej pomocy jest rozumiane i przedstawiane jako zadanie dla Kościoła, jako jego obowiązek. Przytoczone poniżej potwierdzenie jest silne powagą dwóch papieży. Kontekst, z jakiego zostało zaczerpnięte, wskazuje, że wspomniany obowiązek dotyczy również wykorzystania wielorakiego świata cyberprzestrzeni.

Bardzo potrzebne wydaje się podjęcie na nowo refleksji nad „wyzwaniami”, jakie stanowią dla Kościoła środki przekazu. Kościół - jak pisał Paweł VI - „czułby się winny przed swoim Panem, gdyby nie używał tych potężnych pomocy” [...]. Kościół w istocie winien nie tylko posługiwać się mediami w celu szerzenia Ewangelii, ale - zwłaszcza dzisiaj - zespalać zbawcze orędzie z „nową kulturą", którą potężne środki przekazu tworzą i rozpowszechniają ${ }^{12}$.

Dobrze będzie też tutaj zwrócić uwagę na pewien problem z terminologią, z tłumaczeniami, który nie jest bynajmniej problemem teoretycznym, ale wskazuje na coś ważnego, na przykład w formie konsekwencji, nastawienia. Sprawa dotyczy programowej nazwy dekretu Vaticanum II o środkach społecznego przekazu. Nazwa ta pochodzi od słów rozpoczynających dokument. Tym samym chodzi o thumaczenie ważnego tekstu i jego konsekwencje. W przekładach polskich dokumentów soboru watykańskiego II - i następnie, gdy mamy do czynienia z upowszechnianiem przesłania w formie cytatów np. w innych dokumentach - dekret rozpoczyna się następująco: „Spośród podziwu godnych wynalazków techniki” ${ }^{13}$, „Wśród niezwykłych wynalazków techniki” ${ }^{14}$. Tymczasem w oryginalnym tekście łacińskim, czytamy „Inter mirifica technicae artis inventa”, w angielskim: „Among the wonderful technological discoveries”, we francuskim: „Parmi les merveilleuses découvertes techniques”, we włoskim: „Tra le meravigliose invenzioni tecniche” ${ }^{15}$. Tutaj środki społecznego przekazu myśli zostały zaliczone do kategorii rzeczy cudownych, zachwycających, pozytywnie zdumiewających, nie zaś tylko godnych podziwu czy niezwykłych.

12 Jan Paweł II, Szybki rozwój..., 2.

${ }^{13}$ Sobór watykański II, Konstytucje, dekrety, deklaracje. Tekst polski, Poznań 1968, s. 78.

${ }^{14}$ Sobór watykański II, Konstytucje, dekrety, deklaracje. Tekst polski. Nowe thumaczenie, Poznań 2002, s. 87.

${ }^{15}$ Dane za www.vatican.va (5.05.2012), podkreślenia moje - W. M. 
Nasuwają się pytania o wierność oryginałowi wskazanych polskich przekładów oraz o to, czy nie mamy do czynienia z oznakami obaw przed mediami. Ze swej strony bł. Jan Paweł II m.in. formułuje bardzo mocne słowa wdzięczności wobec Boga za rolę, jaką odgrywają media w realizacji Bożych dobroczynnych zamierzeń odnośnie do dobra doczesnego i, co trzeba podkreślić, do dobra wiecznego: ,środki przekazu są opatrznościowym darem Bożym, który ma służyć głoszeniu Ewangelii i postępowi ludzkiemu" "16. W noszącym tytuł Religia w mass mediach przesłaniu na Dzień Środków Społecznego Przekazu w 1989 roku papież wyraża wdzięczność ludziom mediów za już mające miejsce wspomaganie duchowości:

W imieniu całego Kościoła pragnę podziękować światu środków przekazu za ilość miejsca poświęcanego religii. Cieszę się, że mogę użyczyć mego głosu, aby podziękować za udzielanie religii miejsca w dziedzinach dokumentacji, dialogu i gromadzenia danych ${ }^{17}$.

\section{Przekaz „żywym” słowem}

Gdy chodzi o cyberprzestrzeń, mass media i duchowość, to słowo mówione w formie na przykład homilii, rozważań czy audycji tematycznych szczególnie związane jest z radiem. Jednak należy też uwzględnić przynajmniej jeszcze telewizję i nagrania udostępniane na różnych nośnikach. Na przykład portal Radio internetowe $^{18} \mathrm{w}$ odpowiedzi na zapytanie o polskie stacje FM z programami religijnymi wymienia 39 rozgłośni ${ }^{19}$, następnie 13 stacji jako polskie stacje internetowe ${ }^{20}$, 2 rozgłośnie jako zagraniczne stacje $\mathrm{FM}^{21}$ oraz jedną w kategorii zagraniczne stacje internetowe ${ }^{22}$. Wystarczy wskazać na Radio Watykańskie i nadawane tam audycje polskie, by wykazać, iż lista nie jest kompletna. Ze swej strony portal Opoka wylicza

${ }^{16}$ Jan Paweł II, Ewangelizacja przez środki społecznego przekazu. Przemówienie do uczestników zebrania plenarnego Papieskiej Rady ds. Środków Społecznego Przekazu (7 III 1996), cyt. za: A. Lewek, Media i dziennikarstwo w nauczaniu Jana Pawła II, Warszawa 2008, s. 214.

${ }^{17}$ Jan Paweł II, La religione nei mass media. Messaggio per la XXIII Giornata Mondiale delle Comunicazioni Sociali (24 I 1989), 6, www.vatican.va (28.10.2011). Por. T. Kornecki, Pozytywny wptyw mediów na relacje rodzinne w nauczaniu Jana Pawła II, „Studia Socialia Cracoviensia” 4 : 2011, s. $107 \mathrm{n}$.

${ }^{18}$ Adres: www.nadaje.com (4.04.2012).

${ }^{19}$ Są to (kolejność za portalem Radio internetowe): Katolickie Radio Ciechanów; Katolickie Radio Płock; Katolickie Radio Podlasie; Katolickie Radio Zamość; Katolickie Radio Zbrosza Duża; Radio Ain Karim; Radio Alex; Radio Anioł Beskidów; Radio eM; Radio Emaus; Radio eR; Radio Fara; Radio Fiat; Radio Głos; Radio Jasna Góra; Radio Maryja; Radio Nadzieja; Radio Niepokalanów; Radio Orthodoxia; Radio Plus Gryfice; Radio Plus Koszalin; Radio Plus Kraków; Radio Plus Lipiny; Radio Plus Łódź; Radio Plus Olsztyn; Radio Plus Podhale; Radio Plus Szczecin; Radio Plus Warszawa; Radio Rodzina; Radio Rodzina Kalisz; Radio VIA; Radio Victoria; Radio Warszawa; Radio Wolność; RDN Małopolska; RDN Nowy Sącz.

${ }^{20}$ Są to (kolejność za portalem Radio internetowe): Boży Głos w Czasach Ostatecznych; Nadzieja.pl; CCM Radio; OPOKA.fm; Radio Azyll; Radio Katolickiej Odnowy; Radio Katolik; Radio Misericordia; Radio rodzina; RDN Religia; Strzelińskie Radio RDEST.

${ }^{21}$ Są to: Rádio Lumen; Radio Proglas.

22 Jest to Radio POMOST Arizona. 
19 rozgłośni diecezjalnych działających w Polsce ${ }^{23}$. A przecież okolicznościowe czy cykliczne audycje radiowe o charakterze religijnym są nadawane także przez innych. Przykładu dostarcza Radio Kielce. Wskazane dane potwierdzają, że radio może być sprzymierzeńcem duchowości, na przykład przez transmisje Mszy Świętych i innych celebracji dla chorych, relacje z pielgrzymek i innych spotkań papieskich. Niekoniecznie muszą to być bezpośrednie transmisje. Ważne jest udostępnianie materiałów archiwalnych na przykład z pielgrzymek Jana Pawła II. W przypadku audycji na żywo atutem jest to, iż słuchacze mogą zadawać pytania, czy nawet prowadzić dyskusję.

Radiofonia internetowa może być tym przydatniejsza, że wymaga mniejszych nakładów finansowych i tym samym może być bardziej dynamiczna, łatwiejsza do zorganizowania, bardziej sprzyjająca spontanicznemu czy charyzmatycznemu zaangażowaniu się. Zasięg nadawanych za jej pośrednictwem treści jest taki, jak dostęp do światowej sieci internetowej. Takie cechy tym bardziej sprawiają, iż szczególnie ważna jest troska o jakość przekazu, czyli o intelektualne i duchowe przygotowanie nadających ${ }^{24}$. Niebagatelnym atutem przekazu mówionego w formie radiowej jest to, iż może on towarzyszyć na przykład przy wykonywaniu innych czynności, nie przeszkadzając, a wręcz ułatwiając ich właściwe wykonanie, pozwalając dobrze spożytkować czas. Bywa, że percepcja jest nawet wtedy lepsza. Podobne uwagi jak na temat radio nasuwają się w związku z przekazem cyfrowym na CD i DVD, gdzie udostępnia się teksty w formie czytanej czy też proponuje się zapisy dźwiękowe homilii, konferencji i rekolekcji.

\section{Słowo pisane}

Znana jest opinia, że motywacja, postępowanie, duchowość w dużej mierze kształtują się przez kontakt ze słowem pisanym ${ }^{25}$. Czy tak pozostanie? Nietrudno napotkać informacje, że czytelnictwo spada, że obecnie raczej odchodzi się od słowa pisanego na rzecz obrazu ${ }^{26}$. $Z$ drugiej strony łatwo zauważyć, iż słowo mówione

${ }^{23}$ Są to: Anioł Beskidów; Katolickie Radio „Fiat”; Katolickie Radio Ciechanów; Katolickie Radio Podlasie; Katolickie Radio Rodzina; Katolickie Radio Zamość; Radio eM; Radio Emaus; Radio eR - Rozgłośnia Archidiecezji Lubelskiej Radio; Nadzieja Radio Plus Radom; Radio Głos - Katolicka Rozgłośnia Diecezji Pelplińskiej; Radio Katolickiej Diecezji Kaliskiej „Rodzina”; Radio RDN; Małopolska Radio VIA; Katolickie Radio Rzeszów; Radio Victoria; Radio Warszawa; Święty Wojciech - Diecezjalna Rozgłośnia Radiowa; Radio „Fara”; Rozgłośnia Archidiecezji Przemyskiej (za: www.opoka.org.pl, 12.05.2012).

${ }^{24}$ Por. M. Drożdż, Człowiek i media: formacja, uczestnictwo, dialog, [w:] Nie lękajcie się. Jan Pawet II i media, red. A. Baczyński, M. Drożdż, Kraków 2011, s. 65n.

${ }^{25}$ Por. K. Dybciak, Karol Wojtyła a literatura, Tarnów, s. 7; J. Kłoczowski, Dzieje chrześcijaństwa polskiego, Warszawa 2007, s. 253.

${ }^{26}$ Por. np. [b.a.], Spada czytelnictwo dzienników. ,, Gazeta Wyborcza” liderem, www.wirtualnemedia.pl (art. z 18.01.2012); A. Rynio, Stowo w procesie wychowania, [w:] Media w wychowaniu chrześcijańskim, red. D. Bis, A. Rynio, Lublin 2010, s. 262n. 
i pisane nie tylko dalej „funkcjonuje”, ale zajęło znaczącą pozycję na przykład w internetowym wszechświecie. Nawet tak nastawiony na obraz przekaziciel, jakim jest telewizja, coraz bardziej korzysta z możliwości dodawania ścieżek dźwiękowych i napisów w różnych językach do wyboru oraz z funkcji telegazety. Wraz z rozwojem naziemnej telewizji cyfrowej należy spodziewać się umocnienia tej tendencji. Nadal istnieją książki i czasopisma w formie drukowanej, a czymś coraz bardziej rozpowszechnionym stają się e-booki i e-czasopisma, w tym o charakterze religijnym $\mathrm{z}$ ukierunkowaniem na różnych odbiorców, także tych najbardziej wymagających, prowadzących zaawansowane badania naukowe. Widać staranie, by dostępne były też materiały archiwalne, także te pochodzące sprzed ery cyfrowej. Jako przykład można wskazać rzymskie Biblica dostępne gratis on-line ${ }^{27}$ oraz Bibles Online, gdzie niestety brak Pisma Świętego w języku polskim ${ }^{28}$. Warto też odnotować możliwości, jakie dają biblioteki cyfrowe lub udostępniane w formie cyfrowej zasoby biblioteczne: nieraz ma to miejsce przez Internet. Internet prezentuje przebogatą i nadal powiększającą się ofertę książek, artykułów, portali, blogów, komentarzy. Istotne jest udostępnianie na portalach ważnych dokumentów i wypowiedzi. Jakie daje to możliwości (np. gdy chodzi o szybkość, zapoznawanie się, o staranie, o zrozumienie), widać na przykładzie wcześniejszych uwag dotyczących soborowego dekretu poświęconego środkom społecznego przekazu myśli. Dzięki www.vatican.va takie zestawienie było dużo łatwiejsze do zrobienia w porównaniu np. z tradycyjnymi możliwościami, związanymi z tekstem drukowanym dostępnym $\mathrm{w}$ bibliotekach. Istotne z punktu widzenia duchowości treści udostępniają w formie pisanej nie tylko portale o charakterze religijnym, jak np. Opoka (www.opoka. org.pl), ale także inne, w tym takie, które potrafią przedstawiać bardzo krytycznie chrześcijaństwo i Kościół katolicki. Przykładu dostarcza Onet, gdzie w dziale Religia - Kiosk - Onet wiadomości można spotkać m.in. następujące artykuły Całun jednak autentyczny?, W imię cnoty, Arabska wiosna-rzeź chrześcijan i fotoreportaże Pielgrzymka papieża do Meksyku².

\section{Obraz statyczny i obraz dynamiczny}

Przez obraz statyczny będziemy tu rozumieli taki obraz, jak w przypadku rysunku czy zdjęcia, w odróżnieniu np. od obrazu filmowego. Przekaz obrazem statycznym był już w starożytności ważnym sprzymierzeńcem duchowości chrześcijańskiej. Obraz statyczny to np. rysunek, malarstwo, mozaika, zdjęcie, rzeźba, architektura. Możliwości jest więc znacząco dużo. Potęguje je potencjał udostępniania takiego przekazu: nie tylko bezpośrednio np. na ulicznych wystawach, billboardach, plakatach,

\footnotetext{
${ }^{27}$ Adres: http://www.bsw.org/Biblica.

${ }^{28}$ Adres: http://www.biblica.com/bibles (1.06.2012).

${ }^{29}$ Dane z: www.onet.pl (4.05.2012).
} 
ale także w periodykach drukowanych, telewizji, Internecie. Szczególne miejsce, ze względu na możliwości przekazu informacji, przypada tutaj właśnie temu ostatniemu $^{30}$. Jak bardzo tematyka religijna jest obecna, jak wiele możliwości otwierają dostarczane przez Internet dane, można się przekonać, wpisując w przeglądarkach internetowych dla wyszukiwania grafiki np. takie słowa, jak „Boże Narodzenie”, „Chrystus”, „ukrzyżowanie”, „zmartwychwstanie”, „, Jan Paweł II”. Nie tylko można zapoznać się, szukać inspiracji w bogactwie graficznym, ale także kopiować pliki, archiwizować, tworzyć bazy danych, kolekcje stanowiące punkt wyjścia do przemyśleń, prezentacji, wystaw. Można zapoznawać się z wielkimi dziełami, dostępnymi w oryginale w odległych muzeach; warta odnotowania jest przynajmniej jeszcze dokumentacja fotograficzna różnych wydarzeń o charakterze religijnym.

To chyba w przypadku filmu, telewizji i Internetu szczególnie zwracano, czy nadal zwraca się uwagę na niebezpieczeństwa grożące $\mathrm{z}$ ich strony poszczególnym osobom oraz społeczności ludzkiej i światu ${ }^{31}$. Gdy chodzi o obraz dynamiczny, to mamy do czynienia z bogatą, wieloraką ofertą kinową, telewizyjną, internetową i choćby jeszcze na nośnikach cyfrowych, jak płyty DVD. Znaczenie przekazu filmowego wzmacnia niebagatelnie Internet przez umieszczane, tak legalnie jak i nielegalnie, fragmenty filmów czy nawet pełne wersje. Zazwyczaj obraz jest tu łączony z dźwiękiem, co potęguje możliwości oddziaływania. Na znaczenie filmu następująco zwraca uwagę Jan Paweł II: „Warto na przykład przypomnieć tutaj liczne filmy przedstawiające życie i mękę Jezusa oraz życie świętych, do dziś przechowywane w licznych filmotekach, które posłużyły ożywieniu różnych form działalności kulturalnej, rozrywkowej i katechetycznej podejmowane przez liczne diecezje, parafie $\mathrm{i}$ instytucje religijne" ${ }^{32}$. Zagadnienie pozytywnego znaczenia filmu dla życia podjęła także Papieska Rada ds. Komunikacji Społecznej i Filmoteka Watykańska, publikując w 1995 roku listę 45 filmów uznanych za szczególnie pod tym względem godne polecenia ${ }^{33}$.

Interesującego przykładu dostarcza film 1920. Bitwa Warszawska w reżyserii J. Hoffmana z $2011 \mathrm{roku}^{34}$. Religia została tam przedstawiona jako bardzo ważna, pozytywna wartość, istotna w życiu, w chwilach trudnych, przełomowych: zarówno

${ }^{30}$ Młodych ludzi określa się m.in. ze względu na wykorzystywanie przez nich Internetu netgeneration lub sieciakmi. Por. K. Pawlina, Pokolenie JP2, www.opoka.org.pl (4.05.2012).

${ }^{31}$ Por. A. Baczyński, Jan Paweł II - nowe otwarcie Kościoła na media, [w:] Nie lękajcie się. Jan Pawet II i media..., s. 13n.

32 Jan Paweł II, Kino nośnikiem kultury i wartości. Orędzie na XXIX Światowy Dzień Środków Społecznego Przekazu 1995 (6 I 1995), www.opoka.org pl (31.08.2011).

${ }^{33}$ Więcej na ten temat por. M. Lis, Kino w stużbie religii, wartości i sztuki. Lista 45 filmów polecanych przez Papieska Radę do Spraw Środków Spolecznego Przekazu, [w:] Ukryta religijność kina, red. M. Lis, Opole 2002, s. 97n; tenże, Religijne filmy niewierzacych twórców, [w:] Media w wychowaniu chrześcijańskim..., s. 317n.

${ }^{34}$ 1920. Bitwa Warszawska, reżyseria Jerzy Hoffman (2011), płyta DVD z materiałami dodatkowymi, wyd. Edipresse Polska S.A., 2011. 
gdy chodzi o duchownych, jak i świeckich. Nie jest to przesłanie nachalne, lecz jednocześnie jednoznaczne, budzące szacunek i sympatię. Jest ono tym bardziej warte wyeksponowania, iż mamy do czynienia z dziełem cenionego reżysera, z obsadą znanych aktorów, z filmem zaadresowanym do jak najszerszej widowni i mającym ukazać jedno z przełomowych wydarzeń w dziejach Polski i świata. Taki film zostaje nakręcony i jest rozpowszechniany w kontekście życia polityczno-społecznego, gdzie nieraz daje o sobie znać nie tylko dystansowanie się, ale nawet wrogość wobec duchownych katolickich oraz szerzej - katolicyzmu. Interesującego przykładu dostarcza też Katyń w reżyserii Andrzeja Wajdy z 2007 roku $^{35}$. Pozytywnie ukazani zostali pierwsi chrześcijanie w Gladiatorze w reżyserii Ridleya Scotta z 2000 roku. Jest tak w wersji pełnej, natomiast brakuje w wersji podstawowej, dostępnej bezpośrednio na DVD, w której nie ma odniesień do pierwszych chrześcijan. Wersję pełną wydawnictwo umieściło $\mathrm{w}$ dodatkach i tym samym informacje o pierwszych chrześcijanach, którzy w czasach Marka Aureliusza i jego następców są bardzo ważnymi protagonistami życia religijnego, społecznego i politycznego w cesarstwie rzymskim, w pewnym sensie zostały schowane ${ }^{36}$.

Szkicując obraz faktycznego czy choćby potencjalnego, obopólnie potrzebnego i korzystnego przymierza między cyberprzestrznią i mediami a duchowością, trzeba wspomnieć o telewizji. Na przykład portal Opoka odsyła do serwisu Programy Redakcji Katolickiej TVP S.A $A^{37}$. Publiczny, państwowy nadawca, jakim jest Telewizja Polska SA, na swoim portalu posiada dział Religia, z rozdzieleniem na programy katolickie (Między ziemiq a niebem; Coś dla Ciebie; My, wy, oni; Słowo na niedzielę; Ziarno; Mam przepis na...; wykaz ten dotyczy pierwszej strony; są też odsyłacze do następnych trzech stron) i programy ekumeniczne (Dzieci różnych bogów; Program redakcji ekumenicznej, i, chyba mylnie tam umieszczone, Pod Twoja obronę) ${ }^{38}$. Trzeba jeszcze wymienić przynajmniej bardzo ważne przecież transmisje z Mszy Świętych czy innych celebracji tak cotygodniowe (nie tylko w niedziele), jak i w związku $\mathrm{z}$ istotnymi wydarzeniami, jak np. pielgrzymki papieskie. Transmisje te są szczególnie ważne dla ludzi chorych i starszych ${ }^{39}$. W związku z możliwościami, jakie daje przekaz na żywo, gdy chodzi o wspólną modlitwę, o budowanie wspólnoty i kształtowanie postaw ludzkich, Jan Paweł II użył określenia „błogosławiona telewizja” ${ }^{\text {" }}$. Przykładem oddziaływania duchowości

${ }^{35}$ Katyń, reżyseria Andrzej Wajda (2007), płyta DVD z materiałami dodatkowymi, wyd. Edipresse Polska S.A., 2008.

${ }^{36}$ Gladiator, reżyseria Ridley Scott (2000), płyta DVD z materiałami dodatkowymi, wyd. Wydawnictwo Bauer, wydanie specjale dla tygodnika „Teleświat”, 2008.

${ }^{37}$ Dane za: www.opoka.org.pl (12.05.2012).

${ }^{38}$ Dane za: www.tvp.pl (4.05.2012).

${ }^{39}$ Szkoda, że transmisje te nie mają miejsca we wszystkie podstawowe święta kościelne, w uroczystość Świętej Bożej Rodzicielki 1 stycznia.

${ }^{40}$ Por. A. Baczyński, Jan Pawet II - blask osoby w telewizji, [w:] Nie lękajcie się. Jan Pawet II $i$ media..., s. 109. 
na telewizję, stawiania jej nowych wyzwań czy wskazywania nowych możliwości, jest transmisja $\mathrm{z}$ trwającej ok. 40 minut, nieprzewidzianej w programie, modlitwy w ciszy Jana Pawła II na Wawelu. Ze względu na swe cechy i możliwości przekaz telewizyjny jest, jak się twierdzi, nastawiony na dynamicznie zmieniający się obraz i towarzyszące mu dźwięki ${ }^{41}$.

Istotne są możliwości, jakie daje Internet, który pozwala zmniejszyć koszty przesyłania informacji, rozszerzyć zakres ich dostępności w czasie i przestrzeni, szybciej reagować na zaistniałe sytuacje, zapotrzebowania, mobilizować do udzielania pomocy. Zarazem oznacza to potrzebę wsparcia, np. w odpowiednim przygotowaniu materiałów, w docieraniu do nich. Mamy tutaj do czynienia z możliwością przekazu programów, np. telewizyjnych. Pojawiają się też inne możliwości, jak np. udostępnianie filmów czy ich fragmentów, zamieszczanie własnych materiałów audiowizualnych, np. krótkich filmów. Ciekawego wglądu w sytuację pod tym względem dostarcza Youtube i inne podobne portale, jak np. www.godtube.com. Podobne uwagi nasuwają się w związku z grami komputerowymi. Np. Apostot. Portal młodzieży katolickiej oferuje zakładkę Gry online - centrum chrześcijańskiej rozrywki z odsyłaczami do 275 gier podzielonych na 7 kategorii (przygodowe, gry akcji, sportowe, „strzelanki”, logiczne, wyścigi i zręcznościowe) ${ }^{42}$. Widać, iż zainteresowanie duchowością i religią nie jest bynajmniej małe, że istnieje odpowiedź na nie.

„Kultura, wiara i komunikowanie to trzy rzeczywistości, między którymi istnieje związek, od którego zależy teraźniejszość i przyszłość naszej cywilizacji, wezwanej do tego, by w coraz pełniejszy sposób wyrażać się w swym wymiarze globalnym"³. Jak stwierdza bł. Jan Paweł II, także w przypadku świata komunikacji cyfrowej, mass mediów człowiek może liczyć na pomoc Bożąa ${ }^{44}$ Cyberprzestrzeń i mass media oraz duchowość są względem siebie potencjalnymi w przyszłości i nierzadko faktycznymi już dzisiaj sprzymierzeńcami. W niniejszym omówieniu akcent celowo został położony na elementach pozytywnych: przy całej świadomości, iż sytuacja jest bardzo skomplikowana, iż istnieją niebagatelne zagrożenia. Za takim rozwiązaniem przeważyły słowa bł. Jana Pawła II: „Bardzo konkretnym, ale może nie dość docenianym polem działania jest utrzymywanie pozytywnych i konstruktywnych więzi - i nieustannego dialogu - ze środkami przekazu"45. Cyberprzestrzeń i media to cenna, a nawet dzisiaj niezbędna pomoc dla duchowości. Także duchowość jest dla cyberprzestrzeni i mediów cenną pomocą, niezbędną. Nie oczekujmy, że przymierze między nimi zawsze będzie łatwe dla poszczególnych stron. Duchowość, media

${ }^{41}$ Szerzej na ten temat por. tamże, s. 112.

${ }^{42}$ Dane za: http://www.apostol.pl (8.06.2012).

${ }^{43}$ Jan Paweł II, Le comunicazioni sociali, strumento di incontro tra fede e cultura. Messaggio per la XVIII Giornata Mondiale delle Comunicazioni Sociali (24 V 1984), 1, www.vatican.va (28.10.2011).

${ }^{44}$ Jan Paweł II, Szybki rozwój..., 13.

${ }^{45}$ Tenże, Nowe formy komunikacji w stużbie Ewangelii..., s. 209. 
i cyberprzestrzeń posiadają swą specyfikę. Jednak duchowość potrzebuje mediów a media potrzebują duchowości i razem mogą one zdziałać wiele dobrego. W jaki sposób to przymierze może owocować, pomaga zrozumieć papież Benedykt XVI:

Chciałbym [...] zachęcić chrześcijan do włączania się z ufnością oraz ze świadomą i odpowiedzialną kreatywnością w sieć relacji, które stały się możliwe w epoce cyfrowej. Nie po to, by po prostu zaspokoić pragnienie, żeby tam być, ale dlatego, że ta sieć jest integralną częścią ludzkiego życia. Dzięki sieci kształtują się nowe i bardziej złożone formy świadomości intelektualnej i duchowej, wspólne przekonania. Także w tej dziedzinie jesteśmy powołani do głoszenia naszej wiary, że Chrystus jest Bogiem, Zbawicielem człowieka i historii, Tym, w którym wszystkie rzeczy osiągają swoją pełnię ${ }^{46}$.

\section{Summary}

\section{The Internet and the mass media the allies of the spirituality?}

The article concerns the relations between the Internet, the mass media and the spirituality. It demonstrates the indicated interactions as the reciprocal, necessary aid advantageous for all these partners, for our civilization, for the single people and for the hole society now and in the future.

\section{Keywords}

Catholic Church, Christianity, culture, Internet, mass media, new technologies, social life, society, spirituality

${ }^{46}$ Benedykt XVI, Nowe technologie komunikacyjne i głoszenie Ewangelii. Orędzie na 45. Światowy Dzień Środków Społecznego Przekazu 2011 (24 I 2011), www.opoka.org.pl (31.08.2011). 